\title{
WHITHER INDONESIA'S ISLAMIC MODERATISM? A Reexamination on the Moderate Vision of Muhammadiyah and $\mathrm{NU}^{1}$
}

\author{
Masdar Hilmy \\ IAIN Sunan Ampel, Surabaya - Indonesia
}

\begin{abstract}
This paper seeks to analyze the moderate ideology of Muhammadiyah dan NU, popularly known as the champion of Indonesia's moderate Islam. Questions to be investigated are: to what extent that NU and Muhammadiyah theologically represent moderatism? Is there any such thing as "moderate Islam" in Indonesia? How can a blueprint of moderate Islam be formulated in the context of Indonesian Islam? The underpinning theoretical assumption upon which this paper is based is that the theological formulation of Islamic moderatism developed by NU and Muhammadiyah can no longer accommodate the latest challenges and demands of the era. In the context of Indonesian Islam, therefore, a representative formulation of how moderate Islam can be constructed is badly needed. What NU and Muhammadiyah have demonstrated so far in the landscape of Indonesian Islam, nevertheless, can serve as a stepping stone towards building a more liable formulation of an Indonesian Islam in the future.
\end{abstract}

Keywords: Islamic moderatism, Muhammadiyah, Nahdlatul Ulama (NU), radical Islamism.

\section{Introduction}

At the 33rd annual conference held by the Association of Muslim Social Scientists (AMSS) on September 24-26, 2004 at George Mason University Law School in Arlington, Virginia, US, with the theme: "Revisioning Modernity: Challenges and Possibilities for Islam", some

\footnotetext{
1 The earlier draft was delivered at the International Seminar on Islamic Studies held by the Director Forum of Postgraduate Programs of Indonesia's Islamic Higher Education at STAIN Jember, 20-21 April 2012.
} 
papers were delivered to criticize and reformulate what and who moderate Muslim is. One of the papers was entitled: "Moderate Islam, Progressive Muslims, Democracy, and Post-Islamism",, underlining that "moderate" Muslims are those who disagree with the use of violence in their ideology and strategy. In the context of the US and the West in general, the concept and praxis of Islamic moderatism may be different from the same concept held by Indonesian Muslims. In the US, the concept of moderatism gives more emphasis on religious mentality and mindset which is self-critical and reflective, prodemocracy and human rights, as well as supportive of secularism as an ideology. The last characteristic of moderatism is undoubtedly problematic if it is viewed in the context of Indonesian Islam.

This paper tries to unravel the "myth" of Indonesia's moderate Islam by analyzing two mainstream religious organizations which have enjoyed their reputation as the champion of moderate Islam: Nahdlatul Ulama (NU) and Muhammadiyah. The questions that are going to be developed throughout are: is it the case that the religious worldviews of the two organizations are moderate in nature? Is there any such thing as typically Indonesian moderate Islam? And, how to construct a viable and workable blue-print of Indonesia's moderate Islam?

In responding tothe above questions, this paper is divided into three parts as follows: (1) discussing the conceptual hurdles of Islamic moderatism; (2) examining the extent to which Muhammadiyah and NU can be classified as "moderate" organizations in the landscape of Indonesian Islam, and; (3) proposing a more established blue-print of moderate vision of Indonesian Islam.

\section{Conceptual Hurdles}

It must be admitted from the outset that the word "moderate" and "moderatism" represents a conceptual nomenclature which is not easy to define. This is partly because its meaning is highly contested among different religious groups and scholars, contingent upon who and where it is defined. ${ }^{3}$ Instead of giving a clear and distinct conceptual

${ }^{2}$ Kamran A. Bokhari, "Moderate Islam, Progressive Muslims, Democracy, and PostIslamism", paper delivered at the $33^{\text {rd }}$ Annual Conference of the Association of Muslim Social Scientists (AMSS), 24-26 September 2004 at George Mason University Law School, Arlington, Virginia, US.

3 John L. Esposito, "Moderate Muslims: A Mainstream of Modernists, Islamists, Conservatives, and Traditionalists," American Journal of Islamic Social Sciences, Vol. 22, No. 3 (Summer 2005), p. 12. 
boundary, the concept of moderatism serves as a hurdle that appeals public debate among Muslims. As a result, while some feel comfortable with the use and attribution of the word, some others do notand even show a strong objection to it as the paper shall demonstrate later.

It is a matter of fact, that the term "moderatism" is not wellacknowledged in the discourse of classical Islamic thought. Its connotation, however, refers to the use of several Arabic words such as al-wasat or tawassut (moderation), al-qist. (justice), al-tawäzun (fairness), al-itidalal (harmony), tasämuh (tolerance). Those words are employed by Muslims to mean a non-violent mode of religiosity in the Islamic tradition. Since the word "moderatism" is understood subjectively by many, it always invites controversies and subjective biases. More importantly, it has never been neutral from the intervention of political and economic interests. As a result, this semantic hurdle results in the difficulty in arriving at a conclusive meaning of what the word "moderate" refers to and who moderate Muslims comprise of.

Based on the explanation above, it is fairly understandable that the question of who moderate Muslims are is not easy to answer. If one refers to the definition of the word "moderate" as provided in an English dictionary, it is found that the term means: 1) average in amount, intensity, quality, etc; not extreme; 2) of or having (political) opinions that are not extreme; 3) keeping or kept within limits that are not excessive. ${ }^{4}$

Within the landscape of Islamic thought and practices, the degree of moderatism is understood differently according to different people, contexts and localities. Despite the fact that the concept of moderatismis generally more-or-less similar in meaning, it is a highly contested concept. In general, it means a middle-path, a choice between the two extreme poles of religious thought. In the tradition of religious thought, those two extreme poles are usually described as alghuluwn -Yusuf al-Qardhawi names it as al-mutatarrif - and the concept of moderatism usually refers to al-wasat or tawassut, whose meaning is middle-path, middle-way or middle-ground. ${ }^{5}$

It is within the above context that a numerous definitions of moderatism can be found. The concept of moderatism in a Muslim

${ }^{4}$ Oxford Advanced Learner's Dictionary (Oxford: Oxford University Press, 1994), p. 798.

5 Al-Wast is translated by Hans Wehr as middle-path. See, Hans Wehr, Modern Written Arabic (Göttingen: Otto Harrassowitz Verlag, 1979), p. 1248. 
majority country such as Indonesia may take different shape from the same concept in a minority-Muslim country such as the US and other Western countries. In Indonesia, the concept of moderatism is used to indicate a particular religious thought or practice that adopts neither two poles of Islamic thought; the typically-Western liberal thought and radical Islamism thought. Outside of the two poles lies the bulk majority of Muslims where everybody would be happily identified as moderate Muslims.

The middle-path mode of religiosity, nevertheless, has been criticized as having an ambiguous position where an authentic religious standing and identity is at stake. This ambiguous position is equivalent to the position of "neither-nor" (la-wa-la, Ar.), a term that points to "no-where" position: neither West nor East, neither right extreme nor left one, neither literalist nor liberalist, and so forth. This ambiguous standing can be interpreted as the absence of theological conviction in one's religious mind and heart. Due to this reason, some rejects this term on the ground of ambiguity in meaning. A trivial question is; if conceptually speaking the concept of Islamic moderatism refers to neither West nor East, neither liberal nor literal, how can the real picture of Islamic moderatism take shape?

The rejection of some to this term is also based on the argument that moderate Islam does not reflect the whole-heartedness in religion $(k \overline{a f f a h})^{6}$. On the contrary, they assume that moderatism reflects halfheartedness in observing Islamic tenets. They further maintain that moderate Islam is a kind of downgraded or reduced version of Islam from the presumably authentic Islam. In their opinion, moderate Islam does not reflect an authentic Islam. Simply put, it represents less Islam. This type of group usually rejects any type of adjective to be attributed to this religion, such as radical, liberal or even moderate. Such an attribution is regarded as allowing Islam to lapse into a fragmented entity. They argue against this position by maintaining that Islam comprises only one entity; neither liberal nor literal, neither liberal nor radical, neither extreme nor moderate. ${ }^{7}$

Another argument rejecting the use of moderatism is that this word is typically Western founded. In other words, it was invented by

${ }^{6}$ M.A. Muqtedar Khan, "Islamic Democracy and Moderate Muslims: The Straight Path Runs through the Middle," American Journal of Islamic Social Sciences, Vol. 22, No. 3 (Summer 2005), p. 40.

${ }^{7}$ Ibid. 
the West without intended consequences. In their mind, in inventing this concept, the West may want to undermine the strength and solidity of Muslims by injecting whatever terms and words that are considered theologically inauthentic and are, therefore, not in line with the spirit of Islam. Such a rejection reminds us to the same rejection among the Islamists to other concepts which are construed as not authentically Islamic simply because they do not find any word in Arabic that is equivalent in meaning to those terms such as democracy, human rights, pluralism and multiculturalism, and the like. ${ }^{8}$ In their view, all of these words do not have any sound and strong basis in the Qur'an and Hadith, the most pristine sources in Islam.

Regardless the above controversy, the concept of moderatism in the context of Indonesian Islam has at least the following characteristics; 1) non-violent ideology in propagating Islam; 2) adopting the modern way of life with its all derivatives, including science and technology, democracy, human rights and the like; 3) the use of rational way of thinking; 4) contextual approach in understanding Islam, and; 5) the use of ijtihad (intellectual exercises to make a legal opinion in case of the absence of explicit justification from the Qur'an and Hadith). Those characteristics are, however, can be expanded into several more characteristics such as tolerance, harmony and cooperation among different religious groups.

In the context of the US, however, moderatism sometimes contains ideological-political-economical biases which are in line with the contemporary condition of the country. The meaning of moderatism is understood from the context of post-September 11 tragedy that destroyed the World Trade Center, the economic icon of the US. The attack of al-Qaeda to the center of civilization and power of the US has been considered as the turning point from where a paradigm shift in understanding the concept of moderatism occurred. Prior to September 11, the concept of moderatism was understood as a non-violent religious variant. After that tragedy, however, the concept has been twisted too far as a result of the contestation of religious ideologies to identify the demarcation lines which differentiate those who side with the West from those who stand for those Islamists.

8 Masdar Hilmy, Islamism and Democracy in Indonesia: Piety and Pragmatism (Singapore: ISEAS, 2010), pp. 165-169. 
It is within the ideological contestation that the concept of moderatism is understood in an overlapping manner as those who support democracy, human rights, secularism, the US policy of war on terror, and the like. In the US press, the moderate Muslims are identified as those who side with the West in political vision or those who are self-critical in their religious thought. ${ }^{9}$ Meanwhile, the term moderate Islam is pejoratively deployed as those whose religious vision is secular and normatively "less Islam." In the US, moderate Muslims are those who adopt the soft version of Islam-such as the John Esposito's, Irshad Manji's and Karen Armstrong's version of Islamwho wish to coexist and live together with the non-Muslims and feel convenient with typically Western values such as liberal democracy and the ideology of separation of religion and the state. ${ }^{10}$

The context of global politics is also another determinant aspect in understanding the concept of Islamic moderatism. ${ }^{11}$ The group of Muslims who do not react fervently to the Israeli-Palestinian conflict, for instance, can be regarded as moderate. Or, in the context of multinational occupation in Afghanistan and Iraq, moderate Muslims are those who do not oppose this occupation, or even support this occupation on the ground of democratization. In short, moderate Muslim group comprises those who do not react overwhelmingly to the international conflicts involving majority Muslim countries on one side, and the West on the other side.

Despite the fact that the term moderate or moderatism is not easy to define, there are common features that characterize the moderate mode of religiosity among Indonesian Muslims. Among the five features of the moderate Islam as mentioned above, it is non-violent ideology that brings all segments of the moderate Muslims within one enclave of Islamic moderatism. The other four features are, however, essentially contested among them. It is within this stream that NU and Muhammadiyah stand as the two exemplary models of Islamic moderatism in Indonesia.

\footnotetext{
${ }^{9}$ Khan, "Islamic Democracy and Moderate Muslims," p. 40.

${ }^{10}$ Ibid.

11 Graham E. Fuller, "Freedom and Security: Necessary Conditions for Moderation," American Journal of Islamic Social Sciences, Vol. 22, No. 3 (Summer 2005), pp. 21-28.
} 


\section{Moderate Islam of Muhammadiyah and NU}

In the Indonesian context, the question would be: what and how does Islamic moderatism look like? Who are individuals and groups of Muslim who can be called moderate; Is it Muhammadiyah, NU, or other organizations? It is indeed a simple question but hard to answer, particularly when one points to the heterogeneity of religious modes in the spectrum of Indonesian Islam. In this case, one cannot deny the fact that Indonesian Islam comprises a vast array of ideology, thought, as well as practice of Muslim community ranging from one extreme to another extreme.

Before one identifies what, who and how moderate Islam is defined in an Indonesian context, a conceptual framework based upon which the definition of moderatism is established is needed. It has to be acknowledged that a conceptual framework of moderatism in the context of Indonesian Islam may take a different shape from that of other Muslim world, wherein Islam as majority or minority religion. Different context of each country does contribute to the distinctiveness of moderatism. Furthermore, the evolution of meaning contained in whatever concept within a particular society will depend on the development of that society. ${ }^{12}$ This means that the meaning of moderatism may evolve according to the development of social and political context of a particular community. It can cover various meanings stretching from one pole to the other one within particular spectrum of moderatism.

The moderate group, in general, occupies the middle-ground within the spectrum of Islamic thought. But if one examines this issue more closely, there are at least the other three layers under this spectrum, ranging from radical-moderatism, middle-ground moderatism, to soft-moderatisme. Radical-moderatism can be characterized as a salafist-minded ideology, thought or movement which suggests the authentic version of religiosity through direct reference to the pristine sources of Islam: the Qur'an and Hadith. They tend to reject the mode of religiosity that accommodates too much the classical Islamic thought. ${ }^{13}$ They also reject the civilization of the West with its all

\footnotetext{
12 William R. Roff (ed.), Islam and the Political Economy of Meaning (London \& New York: Routledge, 1987).

${ }^{13}$ John Obert Voll, Islam Continuity and Change in the Modern World (Syracuse, New York: Syracuse University Press, 1994), p. 111.
} 
derivatives such as democracy, human rights, civil society, and the like, through peaceful means, and not through violence.

In the context of identity and ideological boundaries of moderatism, Erich Kolig and Greg Fealy, through their respected research project maintain that the concept Islamic moderatism does not constitute clear-cut and black-and-white boundaries. ${ }^{14}$ This is partly because Islamic moderatism is not supported by an authentic and solid theological argument that forms a unified color of moderate Islam. Claims of moderatism tend to be based on the absence of extremity in responding particular religious issues. The majority of moderate Muslims, in my theoretical assumption, have been occupied by the so-called "floating mass" which is not supported by a complicated theological and philosophical "thick description". ${ }^{15}$

This "floating mass" comprises some group of Muslims that tend not to fully care about the basic argument in their religious understanding and attitude. ${ }^{16}$ The reference in their religiosity is merely based on sociological factors that can lead to the process of decision making commonly undertaken by the majority group. This means that the tendency of their religious attitude depends very much on pragmatic-sociological considerations, not on a deep and reflective theological argumentation or religious narrative. As a result, their religious attitude and thinking tend to go along with current streams; they are readily to change their religious attitude contingent upon religious practices popularly observed in the society. Simply put, such a religious manifestation can be considered as banal religious practices or-in figh terminology is called as-taqlid, that is, the most common layer of Muslims which occupies the lowest stratum of religious community. They are characterized by the uncritical consumption of whatever produced by religious elites.

The same case occurs in the discussion of radical and liberal Islam. The group of moderate Muslims occupies the middle-ground between the two extreme poles that give them more rooms of movement.

14 Greg Fealy, "Islamic Radicalism in Indonesia: The Faltering Revival?," Southeast Asian Affairs 2004 (Singapore: Institute of Southeast Asian Studies, 2004), pp. 104-121; Erich Kolig, "Radical Islam, Islamic Fervour, and Political Sentiments in Central Java, Indonesia," European Journal of East Asian Studies, 4, No. 1 (2005), p. 57.

15 Masdar Hilmy, "Moderatisme Islam Indonesia," Kompas, 22 October 2011, p. 6.

16 In a typically-Indonesian sociological language, this "floating mass" may overlap with abangan (nominal) Islam or nationalist Islam. 
Ideologically speaking, radical Islamist thinking can easily exercise influence over, or even further take sympathies from, that "floating mass" moderate Muslims. This means that it is the moderate Muslims as the closest party that can easily be infected by the ideology and thinking of radical Islamism, and not the liberal Muslim group. On the contrary, this "floating mass" moderate Muslims cannot easily move to the side of liberal pole, because intellectually speaking these liberal Muslims are deeply-learned in Islamic sciences, while the "floating mass" moderate Muslims are not. It has to be admitted that the bulk majority of liberal Muslims comprises the moderate Islam, but not from the wing of the above "floating mass".

Some of the students of Indonesian Islam studies are consistent in arguing that Islam in this country comprises the moderate version of Islam. ${ }^{17}$ This moderate position is represented, for instance, by the largest two religious organizations in Indonesia: Nahdlatul Ulama (NU) - popularly known as traditionalist-and Muhammadiyahpopularly known as modernist. The two organizations can be classified into moderate Islam due to their non-violent theological standpoint. These two organizations, in addition, agree with the idea of Unified State of the Republic of Indonesia (NKRI, Negara Kesatuan Republik. Indonesia), one of the most latent issues propagated by Muslim hardliners in the country. For both of them, the form of Unified State of the Republic of Indonesia, with Pancasila as its ideological basis, UUD 1945 as its constitution basis, and Bhinneka Tunggal Ika as its slogan, are considered to be able to accommodate the substantive elements of moderate Islam, the theological vision of which is blessing for all universe (raḅmatan li al-'alamin).

In terms of modern values, both organizations by and large do not show resistance to democracy and human rights, two most paramount values of modernity. ${ }^{18}$ Democracy, they argue, is seen not only as the universal value that is workable in developed Western countries, but it can also be pulled out from the pristine sources of Islam, i.e. the Qur'an and Hadith. In their argument, Islam is, by definition, in line

17 Azyumardi Azra, Indonesia, Islam, and Democracy: Dynamics in a Global Context (Jakarta: Equinox Publishing, 2006), pp. 60-64.

${ }^{18}$ Masykuri Abdillah, Responses of Indonesian Muslim Intellectuals to the Concept of Democracy (Hamburg: Abera Verlag Meyer \& Co. KG, 1997). See also, Robert W. Hefner, Civil Islam: Muslims and Democratization in Indonesia (Princeton: Princeton University Press, 2000). 
with the modern values of democracy and human rights, the two most supreme pillars for the existence of humanity and nations. ${ }^{19}$ Islam is in itself democratic and, therefore, no point of refuting this proposition. There are a lot of cultural aspects of tradition in Islam which are later on subject to change and reform. It is a matter of fact that Islam proves to be able to leave its black history of slavery in the past.

In addition to the acceptance of modern values, Indonesian Islam-with particular reference to the above two organizations-has received its high-profile image as a home to the tradition of religious pluralism and tolerance. ${ }^{20}$ Genealogically speaking, Indonesian Islam has been championing its reputation for being tolerant version of Islam since its very first inception in the country. Indonesia itself has a long tradition of religious tolerance, far before Islam came to the Archipelago and became the majority religion in this country. Indonesian Islam has an interconnected link to the tradition of tolerance of the Hindu-Buddhist era, in which a great number of Hindu and Buddhist temples stood side by side within a particular historic site. ${ }^{21}$

The question would be, is it the case that all members and followers of NU as well as Muhammadiyah can be guaranteed to have a moderate ideology as explained above? Following the thinking spectrum sketched above, the writer tends to argue that not all members and followers of the two organizations have a moderate mode of religious thinking. If it is explained in a more detailed, the typology of members and followers of the two organizations can be sketched into three main clusters as follows: 1) radical-moderate, 2) middle-ground-moderate, and 3) soft-moderate.

The first cluster refers to a group of individuals whose ideological and religious vision is puritan in nature. This cluster has a closer emotional and ideological link to hard-line ideology. Some of them have even metamorphosed ideologically into a hard-line movement and have been part of the rank-and-files in such religious movements as Hizbut Tahrir Indonesia (HTI), Majlis Mujahidin Indonesia (MMI),

\footnotetext{
${ }^{19}$ See, for instance, Robin Bush, Nabdlatul Ulama and the Struggle for Power within Islam and Politics in Indonesia (Singapore: ISEAS, 2009), p. 187.

20 Douglas Ramage, Politics in Indonesia: Democracy, Islam, and the Ideology of Tolerance (London \& New York: Routledge, 1995).

21 M.C. Ricklefs, "Six Centuries of Islamization in Java," Nehemia Levtzion (ed.), Conversion to Islam (New York: Holmes \& Meier Publishers, Inc., 1979), pp. 100-128.
} 
Abu Bakar Ba'asyir's-led Jamaah Anshorut Tauhid (JAT), and the like. Those hard-line groups make the members of NU-Muhammadiyah as their prime target in da' wah (propagating) activities. In this context, it is not exaggerating that in some parts of East Java, there are some NU elites who are identified as the spokesman of HTI.22

On the other hand, the group of soft-moderatism refers to the bulk segment of Muhammadiyah and NU mostly occupied by the "floating mass" - or non-devout-Muslims with limited knowledge about religion. This second group occupies the lion-share of the two organizations. Since their religious understanding and attitude is due to sociological-pragmatic factors, they are the most vulnerable to be potential recruits of hard-line movement. This is so particularly when they meet a particular hard-line cleric (murabbi) and they get tempted by the theological arguments of the murabbi that usually lead to internal conversion among them. It is this kind of theological encounter that can explain the phenomenon of internal conversion among Muhammadiyah and NU communities from moderate to radical ideology.

The third moderate cluster consists of those who are usually deeply-learned in religious sciences and or affiliated to pesantrens. So far, they have crucial position among their communities and play a key role in the process of social transformation within their respected environments. In terms of religious trends, they serve as the makers, producers or trendsetters of religiosity for the common people. They are mostly Muslim scholars (kyai) or pesantren alumni, both from traditional as well as modernist pesantrens, who are deeply-versed in classical and modern Islamic sciences. This cluster represents the important makers of Islamic moderatism projects in Indonesia who are responsible for transforming the religious awareness among millions of members and followers of the two organizations.

Quantitatively speaking, this cluster perhaps represents a small number of the segment of moderate Muslims-perhaps far less than the two earlier clusters. This cluster nevertheless occupies the most important social class within the structure of moderate Muslims in

\footnotetext{
22 This is based on research findings by Rubaidi, a doctorate student of the Postgraduate Program of IAIN Sunan Ampel Surabaya. See, Rubaidi, "Pergeseran Kelas Menengah NU: Studi tentang Pergeseran Ideologi dari Moderat ke Islamisme dan Post-Islamisme di Jawa Timur" (Surabaya: IAIN Sunan Ampel Surabaya, unpublished Ph.D. Thesis, 2012).
} 
Indonesia that is in turn able to inspire millions of followers by means of powerful moderate ideas. It is this last cluster that has been much expected in mainstreaming and producing a well-established and workable blue-print of Indonesia's Islamic moderatism in the future.

In addition to the positive record about the acceptance of the two mainstream organizations to the NKRI, Pancasila, UUD 1945, Bhinneka Tunggal Ika, as well as modern values, there is another characteristic of Islamic moderatism which is commonly accepted in the Western perspective but rejected by the two: secularism. Almost all-not to say all-Indonesia's moderate Islam reject the idea of secularism on the grounds that it consists typically-Western bounded moderatism which is not applicable in the context of Indonesian Islam.

The rejection of the majority toward secularism, indeed, needs robust empirical data which justifies further investigation. As far as Indonesian Islam is concerned, secularism is not a familiar term for the majority of Indonesian Muslims despite the fact that in practice secularism has been an unstated part of their daily life. ${ }^{23}$ This is simply because most of the Indonesian Muslims do not feel comfortable with the idea of separation between religion and the state. The classical nomenclature of Islamic thinking only acknowledges the doctrine of Islam as religion (din) and state (dawlab). ${ }^{24}$ In other words, secularism has been perceived by many as an "alien" in the landscape of Indonesian Muslims' thinking and practice.

The degree of Indonesia's Islamic moderatism is frequently determined by how Muslims approach and understand the sacred texts (the Qur'an and Hadith). Those who rely heavily on context in understanding the texts have been referred to as moderate Muslims. On the other side, the Muslim group who tend to employ literal approach to those texts has been considered as radicals. ${ }^{25}$ The use of

${ }^{23}$ In Abdurrahman Wahid's formulation, the type of secularism adopted within the context of Indonesian Islam is soft or mild secularism. See, Abdurrahman Wahid, “Indonesia's Mild Secularism," S AIS Review 21, No. 2 (Summer-Fall 2001), pp. 25-27.

${ }^{24}$ For further information on doctrine of indivisibility religion from politics in Islam, see, among others, Dale F. Eickelman and James Piscatori, Muslim Politics (Princeton, N.J.: Princeton University Press, c1996); See also, James P. Piscatori, Islam in a World of Nation-States (Cambridge: Cambridge University Press, 1986); cf. Nazih Ayubi, Political Islam: Religion and Politics in the Arab World (London \& New York: Routledge, 1991).

${ }^{25}$ See, for instance, Firman Noor, "Comparison of the Political Perceptions between Radical Islam and Moderate Islam in Indonesia in the Reform Era," Jurnal Penelitian Politik, Vol. 2, No. 1 (2005): pp. 13-33. 
these two approaches can be seen, for instance, in understanding the form of ideal State in Islam. Regarding this issue, the moderate Muslims tend to employ modern reference in building their arguments on the ideal form of state in Islam. Such methodological reference usually leads to the conclusion that Islam does not provide a prescriptive and conclusive clue of what an ideal form of the state in Islam constitutes. The radicals, however, tend to pull some keywords out of the sacred texts in literal sense to be treated as the ideological basis for an Islamic state. This can be seen, among others, in the case of Caliphate doctrine as propagated by HTI as a translation of the word kbilafab in the Qur'an. ${ }^{26}$

Be that as it may, drawing a firm line between the radical Muslims from moderate ones can be theoretically misleading. This is because each group does not apply its methodological approach strictly and consistently. The most current condition of Indonesian Islam has been characterized by the tendency of mutual exchange in methodology between the two poles. There are times when the radicals are convenient with contextual approach in understanding a particular religious doctrine. On the contrary, there are times when the moderates feel comfortable with literal approach. This can be seen, for instance, from the fact that a great number of radicals are no longer bothered with the use of modern technology, whereas their fellow moderates can be quite conservative in accepting modern technology.

\section{In Search for Indonesia's Islamic Moderatism}

Theological system which is in itself sufficient to support the conceptual framework and praxis of religious mode of moderatism would be sine qua non within the landscape of Indonesia's Islamic moderatism. It must emanate the country's public sphere if it wishes to provide a moderate vision of Islam. So far the concept of Islamic moderatism has been juxtaposed with external modalities such as cultural-spiritual heritage of the nation's predecessors pulled out from non-Islamic elements. It is time now that an authentic version of Islamic moderatism must be drawn from within the internal sources of Islam in order to formulate a blue-pint for Indonesia's Islamic moderatism, that is, an internal modalities-based version of religious moderatism.

\footnotetext{
${ }^{26}$ See, for instance, Hilmy, Islamism and democracy in Indonesia, pp. 160-63.
} 
Nuhammadiyah and NU must be acknowledged as religious organizations that pioneered the making of moderate mode of religiosity regardless the complexity to put this mode into practice. The formulation of such a blue-print is inspired directly by normative values in Islam on the one side. This formulation, however, suffers from the lack of "thick theological description" which guides the pattern of Islamic moderatism in a more thoughtful but practical manner. In spite of this shortcoming, this formulation can be seen as a "local genius" of actualization of religious doctrines which may not be found in any part of the Muslim world. In a more or less similar formation, Malaysia has the formulation of "Hadhari Islam", a nomenclature of Islamic thinking specifically designed to accommodate an ideological battle between the dimension of al-asalah (authenticity) and the dimension of al-hadarah (modern contemporary civilization) in religion..$^{27}$

Almost similar to the formulation of Hadhari Islam in Malaysia, this country has also witnessed a religious articulation called "masyarakat madan" (simply translated as civil society). ${ }^{28}$ The interesting thing about "masyarakat madani" is that although the term does not carry religious connotation, its connotation has been much religious because it is directly inspired by normative Islam. Initiated by a group of modernist Muslim intellectuals-scholars in early 1990s, "masyarakat madani" has become a nomenclature of Islamic politics praised by many to represent the model of Indonesia's Islamic civility. "Masyarakat madan " represents an overwhelming sprout of Muslim middleclass on the stage of national politics, where they had been marginalized by the state in the Old Order and early New Order era. More importantly, "masyarakat madan"" represents the version of moderate Islam that combines dimension of modernity and dimension of primordial religious identity.

Viewed from its long historical journey since the acceptance of Pancasila as the only ideological foundation of the state in the 1984 Situbondo Congress-lately popularly known as The Return to the 1926 Khittah-NU has shown the pendulum movement of its

27 Terence Chong, "The Emerging Politics of Islam Hadhari," in Saw Swee-Hock \& K. Kesavapany (eds), Malaysia: Recent Trends and Challenges (Singapore: Institute of Southeast Asian Studies, 2006), pp. 26-46.

${ }_{28}$ M. Dawam Rahardjo, Masyarakat Madani: Agama, Kelas Menengah, dan Perubahan Sosial (Jakarta: LP3ES, 1999). 
religiosity into the middle-ground moderatism. The historical journey of Nabdliyin (the followers of NU) has shown a fairly extreme degree of intensity and ups-and-downs as well as diverse internal dynamic. In its latest development, NU has even received ideological challenges from hard-liner Muslims to question the normative foundation of Islamic moderatism.

In order to support the foundation of Islamic moderatism, some outstanding NU founding scholars (kyais)—such as KH. Achmad Siddiq, KH. Ali Maksum, KH. As'ad Syamsul Arifin and others-have formulated a road-map to the doctrine of Islamic moderatism which is called as the theology of abl al-sunnah wa al-jamäah (frequently abbreviated as Aswaja). ${ }^{29}$ The literal meaning of aswaja is the holder of the Prophet's pathway and communion which is a kind of code of piety shown by the Prophet, his Companions and pious predecessors (al-salaf al-salih) expected to guarantee the purest form of religion. ${ }^{30}$

The theological construct of NU's moderatism is bolstered by the doctrinal "trilogy" as follows: al-tawassut (moderation or middleground), itidal (straight-path, neither left nor right leaning), and altawazun (equilibrium, fairness in treating the worldly affairs and the hereafter). ${ }^{31}$ The concept of al-tawassut is derived from a verse of the Qur'an (2: 143), itidial is from, 5: 8), and al-tawä̌n is from QS alHadid: 25. The manifestation of the thee principles and characteristics mentioned above, according to some NU kyais, must be explicitly exposed in all key aspects of Islam such as faith ('aqidab), Islamic law (shari' $\left.{ }^{\prime} a b\right)$, tasawwuf (Sufi) and akbläq (social ethics), mu'asarah (social conduct), in the field of nation-state, culture and civilization, Islamic propagation (da wah), and some other sectors. ${ }^{32}$

As a modality, the formulation of Aswaja serves only as an embryo for the making of the blue-print, and not the blue-print itself. It is not an ideal formulation that accommodates all new tendencies in far more

${ }^{29}$ Djohan Effendi, Pembaruan tanpa Membongkar Tradisi: Wacana Keagamaan di Kalangan Generasi Muda NU Masa Kepemimpinan Gus Dur (Jakarta: Penerbit Buku Kompas, 2010), p. 263.

$30 \mathrm{KH}$. Achmad Siddiq, Kbittab Nabdliyyab (Surabaya: Khalista in collaboration with LTN-NU Jawa Timur, 2006), p. 27.

31 KH. Abdul Muchith Muzadi, NU dalam Perspektif Sejarah \& Ajaran (Refleksi 65 Th. Ikut NU) (Surabaya: Khalista, 2007), pp. 69-71.

32 Ibid., pp. 72-73. 
complex and challenging religious life. In accompaniment of the religious formulation of $\mathrm{NU}$ and pesantren is the use of some other methodological apparatus to approach Islam through the two pristine sources: the Qur'an and Hadith. The methodological approach comprises usul al-figh (principles of jurisprudence) and other methodological apparatus such as maslahah (public good), istibsan (utility), istihsab (recommended norms), qawl sahäbi (legal opinions of the Prophet's Companions), shadd al-dhara'i ' (closing the direction to sins), and so forth. ${ }^{33}$

The use of the above methodological apparatus in the stream of religious thought in NU circles can be analogized as a double-edged sword. On the one side it tends to eternalize religious orthodoxy as a result of indirect referencing system towards the Qur'an and Hadith. Such an indirect referencing system, however, can generate the room of experimentation and articulation of thinking that can, in turn, lead to the making of creativeness and freedom of thinking by utilizing the methodological apparatus particularly during the Islamic law making process (istinba $\bar{t}$ ). It has to be admitted that the intellectual tradition of $\mathrm{NU}$ is created due to the habitual rehearsals of these intellectual exercises in responding and solving some contemporary issues. This, in turn, leads to the making of intellectual tradition among the younger generation of $\mathrm{NU}$ that produce groundbreaking approaches that enrich the old paradigm in the horizon of intellectual methodology among the older generation of NU. The tendency of progressive, or even liberal, intellectual tradition among the younger Nabdliyin (the followers of $\mathrm{NU}$ ) represents the functioning of the methodological apparatus in the dialectics of contemporary Islamic thought in Indonesia. ${ }^{34}$

33 There is an intellectual tradition of NU in approaching and solving contemporary issues called Lajnah Babtsul Masa'il, in which three methodological approaches used by the kyais in the new law making process: 1) qawli (result) approach; 2) ilhaqa $\bar{i}$ (analogy) approach, and; 3) manhajīi (methodology) approach. For further information about this, see, Ahmad Zahro, Tradisi Intelektual NU: Lajnab Babtsul Masa'il 1926-1999 (Yogyakarta: LKiS, 2004), p. 170.

${ }^{34}$ Laode Ida, NU Muda: Kaum Progresif dan Sekuler Baru Jakarta: Penerbit Erlangga, 2004); See also, Shonhadji Sholeh, Arus Baru NU: Perubaban Pemikiran Kaum Muda NU dari Tradisionalisme ke Post-tradisionalisme (Surabaya: JP Books, 2004). See also, Hairus Salim H.S. and Muhammad Ridwan (ed.), Kultur Hibrida: Anak Muda NU di Jalur Kultural (Yogyakarta: LKiS, 1999). 
On the other side, the appreciation towards the use of methodological apparatus and the tradition of Islamic thinking as much developed by the younger generation of NU have received less attention among the followers and members of Muhammadiyah, due to the deep institutionalization of the slogan "the return to the Qur'an and Hadith" (al-ruju', ilà al-Qur'an wa al-Hadith). ${ }^{35}$ This does not necessarily mean that the younger generation of Muhammadiyah do not arise the same awareness as that of the younger generation of NU in revitalizing the spirit of revivalism (tajdid). In responding to the stagnation of reform movement, some concerned younger generation of the Muhammadiyah founded a similar association as NU younger generation's Jaringan Islam Liberal (Liberal Islam Network), called Jaringan Intelektual Muda Muhammadiyah, abbreviated as JIMM, (Network of Muhammadiyah Young Intellectuals). Founded by some progressive young generation of Muhammadiyah such as Zuly Qadir, Abd Rahim Ghozali, Hilman Latief, and others on 9 October 2003, JIMM wishes to bring the revivalist spirit back home to Muhammadiyah. ${ }^{36}$

Interestingly, in the context of Indonesian Islam, the use of methodological apparatus in the process of reform actually had been introduced for the first time by Muhammadiyah, not NU. ${ }^{37}$ The founding of Muhammadyah was inspired by the misery of some Muslim elites in response to the backwardness of the Muslim community as a whole. It is this misery that in turn inspired the embryo of the reform movement of Islamic thought (tajdid and ijtiba $\bar{a}$ ), where in NU circle it had been considered closed since the third Hijriyah century. ${ }^{38}$ Without the pioneering movement undertaken by Muhammadiyah, it is impossible to see the moderate face of Islam as can be seen today. Thanks to this organization, the idea of reform has become a familiar vocabulary for Indonesian Muslims. Due to its real

\footnotetext{
35 Moenawar Chalil, Kembali kepada Al-Qur'an dan as-Sunnah (Djakarta: Bulan Bintang, 1956).

36 Suaidi Asyari, Nalar Politik NU \& Muhammadiyab: Over Crossing Java Sentris (Yogyakarta: LKiS in collaboration with Center for the Study of Contemporary Indonesian Islam and Society, 2009), p. 262.

37 Ahmad Jainuri, Ideologi Kaum Reformis: Melacak Pandangan Keagamaan Mubammadiyah Periode Awal (Surabaya: Lembaga Pengkajian Agama dan Masyarakat [LPAM], 2002), p. 105.

${ }^{38}$ Ibid., p. 107.
} 
contribution, it is not exaggerating that Muhammadiyah was attributed as a modernist organization in the country. ${ }^{39}$

The attribution of Muhammadiyah as a modernist organization is due to its positive vision toward modernity. Through its methodological apparatus, i.e. tajdid, Muhammadiyah started to launch a series of reform movement within the body of Indonesian Islam. Despite strong resistence from the traditionalist Muslims, the Muhammadiyah's reform has been at the point of no return, and later proved to appeal the sympathy and membership from the traditionalist Muslims. One of the examples of the Muhammadiyah reform movement that was rejected by the traditionalists but now becomes commonplace is the change of sermon language of Friday prayers and two Ied prayers from Arabic — as had been commonplace among traditionalists-into local and national languages. ${ }^{40}$

In addition to functioning as a stepping stone for reform movement, the slogan "the return to the Qur'an and Hadith," however, may function as a factor that causes stagnation for Muhammadiyah reform movement. ${ }^{41}$ Like a double-edged sword, this slogan has played two roles at once. On the one side, this slogan has played its function well as the pioneer of reform movement in Indonesia. But when the reformed version of Islam has been instituted, this slogan can lead to the establishment of religious orthodoxy and make Muhammadiyah puritan in nature. ${ }^{42}$ This is one of the most salient characteristics of epistemological traps derived from the slogan "the return to the Qur'an and Hadith." The stagnation of reform has been the critical issue directed to Muhammadiyah, especially when its younger generation unified in JIMM who wish to reinvigorate the spirit of tajdid

39 Deliar Noer, The Modernist Muslim Movement in Indonesia: 1900-1942 (Singapore: Oxford University Press, 1973).

40 W. Sairin, Gerakan Pembaruan Mubammdiyah (Jakarta: Pustaka sinar Harapan, 1995). See also, Abdul Munir Mulkhan, Kiai Abmad Dablan: Jejak Pembaruan Sosial dan Kemaanusiaan, Kado Satu Abad (Jakarta: Penerbit Buku Kompas, 2010), p. 236.

41 Suaidi Asy'ari, “A Real Threat from Within: Muhammadiyah's Identity Metamorphosis and the Dilemma of Democracy," Journal of Indonesian Islam, Vol. 01, No. 01 (June 2007): pp. 18-41.

42 This reminds us to what Peacock has found out in his book that Muhammadiyah constitutes a puritanical Muslim organization. See, James L. Peacock, Muslim Puritans: Reformist Psychology in Southeast Asian Islam (Berkeley and California: University of California Press, 1978). 
has been resisted and marginalized by the older generation of this reformist organization. ${ }^{43}$

In contrast to what Muhammadiyah has undergone, the employment of methodological apparatus among the young Nabdliyyin does not give credits to NU as a reformist or modernist organization, albeit some epistemological leap in the use of methodological means among the young Nabdliyyin thanking to their mobilization in tertiary formal education. Furthermore, NU's traditional identity is caused by the overwhelming appreciation toward the horizon of classical thought of Muslim scholars as contained in yellow books (kitab kuning) of the pesantren. ${ }^{44}$ It is due to this reason that the Nabdliyyin have been criticized as being traditional in the way they approach and understand Islam and the world.

Regardless its association to the traditional stigmatization, the overwhelming reliance on the use of classical Muslim scholars' horizon can serve as a stepping stone toward the epistemological leap in Islamic thinking methodology. This is because everything sometimes can function in two contradictory ways; on the one hand it can function in a negative way, on the other hand it can function as a positive and productive way. On the one hand it can lead to regression buton the other hand it can be the modality toward the progression. This is the analogy of double-edged sword function in explaining both the progressive movement and the regressive one within Muhammadiyah and NU. In relation to the Nabdliyyin's appreciation to tradition of classical Islamic thought, their reliance on such a classical tradition can mean a lot to the making of renewal and reform movement among the young Nabdliyyin. ${ }^{45}$

Apart from what the above two moderate organizations have achieved, the search for Islamic moderatism in Indonesia needs a more expansive, deeper and more thorough perspective on moderatism

\footnotetext{
43 This resistance has resulted in, among others, the victimization of young progressive thinkers, such as Muhammad Shofan, who had been fired as a lecturer from Muhammadiyah University of Gresik, East Java.

44 Martin van Bruinessen, Kitab Kuning, pesantren, dan tarekat: Tradisi-tradisi Islam di Indonesia (Bandung: Mizan, 1995); See also, Idem, "Kitab Kuning: Books in Arabic Script Used in the Pesantren Milieu," Bijdragen tot de Taal-, Land-en Volkenkunde 146 (1990), pp. 226-269.

45 Martin van Bruinessen, NU: Tradisi, Relasi-relasi Kuasa, Pencarian Wacana Baru (Yogyakarta: LKiS, 1994), p. 25.
} 
which is derived from internal values of classical Islam. It has to be admitted that the concept of Islamic moderatism has not been developed from a strong and detailed theological basis. The concept of Islamic moderatism relies heavily on external aspects of Indonesian culture and society. The externality has dominated the theological construct of Islamic moderatism in Indonesia. The immediate impression from Islamic moderatism in Indonesia, however, is that, it is Indonesian [culture] factor, and not Islam one, that contributes to the making of Islamic moderatism. The fact is that Indonesia has enjoyed its reputation for its abundant tradition of tolerance, respect and harmony. In this context, Islam has come into such an established web of tradition as an outsider that flourishes the local tradition of tolerance.

The attempts at formulating the concept of Islamic moderatism in the end are determined by the way Muslims approach and understand the Qur'an and Hadith. The return to both sources is epistemologically problematic and deserves due consideration if Muslims wish to achieve an authentic concept of Islamic moderatism. Nevertheless, there are times when Muslims do not have many choices except returning back to the Qur'an and Hadith as an ethical basis in developing a more workable concept of Islamic moderatism. It is noteworthy that both radical and moderate Muslims equally treat both of them in a supreme position as the normative basis for developing an appropriate code of conduct. The term "normative basis," however, can mean differently for each of them; starting from the direct reference in literal sense to merely as a source of inspiration. In terms of ethics, there are a lot of things that need a direct referencing to both sources and, therefore, can be accepted as they are; but there are other things that need to be taken in spirit, not in literal sense. It is within this context that the degree of Islamic moderatism will be at stake.

From the above explanation, it can be said that the concept of Islamic moderatism in Indonesia has been developed centripetally. Now, it is the time that the concept must be developed centrifugally in order to maximize the internal sources of Islam as the first reference in producing a blue-print of Islamic moderatism. If the first mode relies on the flexibility of Islam as an outsider to adapt itself to the local condition of the country, the second mode relies on Islam as internal modality to develop a more established blue-print of Islamic moderatism in order to draw its relevance to local condition of 
Indonesia. It is within this context that what Fazlur Rahman has called as "double-movement" approach is worth referencing through backand-forth consultation in terms of reconciling between modernity and traditionalism in the spectrum of Islamic thought. ${ }^{46}$

\section{Conclusion}

To sum up, Indonesian Islam has a high-profile of moderatism through Muhammadiyah and NU, the two exemplary models of moderatism. The moderate theology of both organizations, however, is no longer sufficient in accommodating the changes and challenges of this modern era. As this article has explained, there are a lot of ways to achieve a more detailed but workable blue-print of Indonesia's Islamic moderatism. It is the time for Indonesian Muslims to prove the world that they have an authentic version of Islamic moderatism which is internally driven. They have to prove that the concept of Islamic moderatism is not a myth, but a down-to-earth reality. In this context, the phenomenon of "internal conversion" occurred among the followers of moderate Islam into radical Islam must be understood as a serious "strike" for the moderate Muslims who are not aware of formulating a more established but workable blue-print of Islamic moderatism. What Muhammadiyah and NU have done so far is a pioneering attempt at the making of Islamic moderatism in Indonesia. Nevertheless, their formulation of moderatism is due to the internal demand of Muslims to create a theological system that fits in with the local condition of Indonesia.

For Muhammadiyah, it is imperative that the followers and or members of this organization must revive the spirit of reform (tajdid) as its branding image since the beginning in order to formulate a theologically more firmed basis for Islamic moderatism. It must be acknowledged that this organization has done a lot for initiating the mode of Islamic moderatism though a series of reform movement in early 1920s. But the overwhelming reliance on the slogan of the return to the Qur'an and Hadith can kill the inner capacity of this organization to develop a more sustainable project on Islamic moderatism from within.

For NU, likewise, the formulation of such key-terms as tawassut, tawärun, i'tidăl and tasamub has to be appreciated as an initial stage in

\footnotetext{
${ }^{46}$ Fazlur Rahman, Islam and Modernity: Transformation of an Intellectual Tradition (Chicago:
} Chicago University Press, 1984), p. 7. 
developing a more established blue-print of Islamic moderatism. This formulation, however, is perceived by some radical Muslims as a "neither-nor" formulation which stands in no-where position within the spectrum of Islamic thought. Some even consider that formulation as less or downgraded version of Islam and, therefore, needs further elaboration and "objectivication" at practical level. In short, the moderation principle developed by NU tends to create less committed character in religiosity. This formulation is likewise not sufficient if NU wishes to contribute to the betterment of the nation. The good principle of moderation should reflect a rigorous commitment to upholding the normative values of Islam without necessarily losing the very characteristic of its civility.

The Islamic moderatism project, above all, should start "from within." It is a matter of fact that such common denominators as Pancasila, UUD 1945, NKRI, and Bhinneka Tunggal Ika-better known as four pillars-are cultural emblems that convey the message of moderation. These cultural emblems, however, have been developed "from without" that lack a sense of being authentic in terms of religious identity. On the contrary, the formulation of Islamic moderatism "from within" will guarantee the sense of authenticity among the Muslim community. By doing so, the foundation of Islamic moderatism in Indonesia will engender a more sustainable Islamic moderatism since it stands on a firm theological ground. []

\section{References}

\section{Books and Articles}

Abdillah, Masykuri. Responses of Indonesian Muslim Intellectuals to the Concept of Democracy. Hamburg: Abera Verlag Meyer \& Co. KG, 1997.

Asyari, Suaidi. Nalar Politik NU \& Mubammadiyab: Over Crossing Java Sentris. Yogyakarta: LKiS in collaboration with Center for the Study of Contemporary Indonesian Islam and Society, 2009.

---------. “A Real Threat from Within: Muhammadiyah's Identity Metamorphosis and the Dilemma of Democracy." Journal of Indonesian Islam, Vol. 01, No. 01 (June 2007): pp. 18-41.

Ayubi, Nazih. Political Islam: Religion and Politics in the Arab World. London \& New York: Routledge, 1991. 
Azra, Azyumardi. Indonesia, Islam, and Democracy: Dynamics in a Global Context. Jakarta: Equinox Publishing, 2006.

Bokhari, Kamran A. "Moderate Islam, Progressive Muslims, Democracy, and Post-Islamism." paper presented at The 33 ${ }^{\text {rd }}$ Annual Conference of the Association of Muslim Social Scientists (AMSS) held on 24-26 September 2004 at George Mason University Law School di Arlington, Virginia, AS.

Bush, Robin. Nahdlatul Ulama and the Struggle for Power within Islam and Politics in Indonesia. Singapore: ISEAS, 2009.

Chalil, Moenawar. Kembali kepada Al-Qur'an dan as-Sunnah. Djakarta: Bulan Bintang, 1956.

Chong, Terence. "The Emerging Politics of Islam Hadhari." in Saw Swee-Hock \& K. Kesavapany (eds). Malaysia: Recent Trends and Challenges. Singapore: Institute of Southeast Asian Studies, 2006.

Effendi, Djohan. Pembaruan tanpa Membongkar Tradisi: Wacana Keagamaan di Kalangan Generasi Muda NU Masa Kepemimpinan Gus Dur. Jakarta: Penerbit Buku Kompas, 2010.

Eickelman, Dale F. and James Piscatori. Muslim Politics. Princeton, N.J.: Princeton University Press, 1996.

Esposito, John L. "Moderate Muslims: A Mainstream of Modernists, Islamists, Conservatives, and Traditionalists." American Journal of Islamic Social Sciences, Vol. 22, No. 3 (Summer 2005).

Fealy, Greg. "Islamic Radicalism in Indonesia: The Faltering Revival?." Southeast Asian Affairs 2004. Singapore: Institute of Southeast Asian Studies (2004): pp. 104-121.

Fuller, Graham E. "Freedom and Security: Necessary Conditions for Moderation." American Journal of Islamic Social Sciences, Vol. 22, No. 3 (Summer 2005): pp. 21-28.

Hefner, Robert W. Civil Islam: Muslims and Democratization in Indonesia. Princeton: Princeton University Press, 2000.

Hilmy, Masdar "Moderatisme Islam Indonesia," Kompas, 22 October 2011.

-------.. Islamism and Democracy in Indonesia: Piety and Pragmatism. Singapore: ISEAS, 2010. 
Ida, Laode. NU Muda: Kaum Progresif dan Sekuler Baru. Jakarta: Penerbit Erlangga, 2004.

Jainuri, Ahmad. Ideologi Kaum Reformis: Melacak Pandangan Keagamaan Muhammadiyah Periode Awal. Surabaya: Lembaga Pengkajian Agama dan Masyarakat [LPAM], 2002.

Khan, M.A. Muqtedar. "Islamic Democracy and Moderate Muslims: The Straight Path Runs through the Middle." American Journal of Islamic Social Sciences, Vol. 22, No. 3 (Summer 2005).

Kolig, Erich. "Radical Islam, Islamic Fervour, and Political Sentiments in Central Java, Indonesia." European Journal of East Asian Studies 4, No. 1 (2005).

Mulkhan, Abdul Munir. Kiai Abmad Dablan: jejak pembaruan sosial dan kemaanusiaan, kado satu abad. Jakarta: Penerbit Buku Kompas, 2010.

Muzadi, KH. Abdul Muchith. NU dalam Perspektif Sejarah \& Ajaran (Refleksi 65 Th. Ikut NU). Surabaya: Khalista, 2007, 2007.

Noer, Deliar. The Modernist Muslim Movement in Indonesia: 1900-1942. Singapore: Oxford University Press, 1973.

Noor, Firman. "Comparison of the Political Perceptions between Radical Islam and Moderate Islam in Indonesia in the Reform Era." Jurnal Penelitian Politik, Vol. 2, No. 1(2005): pp. 13-33.

Oxford Advanced Learner's Dictionary. Oxford: Oxford University Press, 1994.

Peacock, James L. Muslim Puritans: Reformist Psychology in Southeast Asian Islam. Berkeley and California: University of California Press, 1978.

Piscatori, James P. Islam in a World of Nation-States. Cambridge: Cambridge University Press, 1986.

Rahardjo, M. Dawam. Masyarakat Madani: Agama, Kelas Menengah, dan Perubahan Sosial. Jakarta: LP3ES, 1999.

Rahman, Fazlur. Islam and Modernity: transformation of an Intellectual Tradition. Chicago: Chicago University Press, 1984.

Ramage, Douglas. Politics in Indonesia: Democracy, Islam, and the Ideology of Tolerance. London \& New York: Routledge, 1995. 
Ricklefs, M.C. "Six Centuries of Islamization in Java." in Nehemia Levtzion (ed.). Conversion to Islam. New York: Holmes \& Meier Publishers, Inc., 1979.

Roff, William R. (ed.). Islam and the Political Economy of Meaning. London \& New York: Routledge, 1987.

Rubaidi "Pergeseran Kelas Menengah NU: Studi tentang Pergeseran Ideologi dari Moderat ke Islamisme dan Post-Islamisme di Jawa Timur." unpublished Ph.D. Thesis, Surabaya: IAIN Sunan Ampel Surabaya, 2012.

Sairin, W. Gerakan Pembaruan Mubammdiyah. Jakarta: Pustaka Sinar Harapan, 1995.

Salim H.S., Hairus and Muhammad Ridwan (ed.). Kultur Hibrida: Anak Muda NU di Jalur Kultural. Yogyakarta: LKiS, 1999.

Sholeh, Shonhadji. Arus Baru NU: Perubahan Pemikiran Kaum Muda NU dari Tradisionalisme ke Post-tradisionalisme. Surabaya: Jawa Pos Books, 2004.

Siddiq, KH. Achmad. Khittah Nabdliyyah. Surabaya: Khalista in collaboration with LTN-NU Jawa Timur, 2006.

van Bruinessen, Martin. "Kitab Kuning: Books in Arabic Script Used in the Pesantren Milieu." Bijdragen tot de Taal-, Land- en Volkenkunde 146 (1990): pp. 226-269.

--------. NU: Tradisi, relasi-relasi kuasa, pencarian wacana baru. Yogyakarta: LKiS, 1994.

--------. Martin. Kitab Kuning, pesantren, dan tarekat: Tradisi-tradisi Islam di Indonesia. Badung: Mizan, 1995.

Voll, John Robert. Islam Continuity and Change in the Modern World. Syracuse, New York: Syracuse University Press, 1994.

Wahid, Abdurrahman. "Indonesia's Mild Secularism." S AIS Review, 21, No. 2 (Summer-Fall 2001).

Wehr, Hans. Modern Written Arabic. Göttingen: Otto Harrassowitz Verlag, 1997.

Zahro, Ahmad. Tradisi Intelektual NU: Lajnah Bahtsul Masa'il 1926-1999. Yogyakarta: LKiS, 2004. 